\title{
Temperature And Humidity Optimization To Add Save Life Strawberry (Fragaria chiloensis, L.)
}

\author{
$\operatorname{Kartika}^{1 *}$ \\ Electrical engineering study program, Universitas Malikussaleh, Lhokseumawe \\ Aceh, Indonesia \\ ${ }^{*}$ Corresponding Author: \\ Email: kartika@,unimal.ac.id
}

\begin{abstract}
.
This study aims to determine the appropriate temperature and humidity in the storage of strawberries, this research was carried out using 3 humidity treatments and 3 temperatures, namely humidity $65 \%, 75 \%$, and $85 \%$ with a temperature of 10 $o C, 15 o C$, and room temperature, fruit fruit stored at room temperature lasts up to 3 days, while at $10 \mathrm{oC}$ the fruit with 65\% humidity treatment lasts up to 6 days, with $75 \%$ humidity for 6 days and with $85 \%$ humidity it lasts for 7 days, at 15 oC the fruit with 65\% humidity treatment lasts 5 days, with 75\% humidity for 5 days and with $85 \%$ humidity lasts for 6 days, so based on research that has been done it is known that $85 \%$ humidity treatment with a temperature of $10 \mathrm{oC}$ is the right storage for strawberries. The longest shelf life of strawberries is with a humidity treatment of $85 \%$ which is stored at $10 \mathrm{oC}$, which can extend the shelf life of 4 days longer when compared to storage at room temperature.
\end{abstract}

Keywords: Strawberry fruit, humidity, temperature, shelf life.

\section{INTRODUCTION}

Strawberry (Fragaria chiloensis, L.) is a horticultural product that has high economic value. Generally, strawberries are marketed at room temperature. This method of marketing will affect the speed of decline in fruit quality and shelf life, as well as affect the availability and marketing of fruit. This fruit is widely consumed in fresh form and also in processed form. According to the Central Statistics Agency (2020), Indonesia's strawberry production in 2017 was 12,225 tons and decreased production by $30.13 \%$ ( 3,684 tons) in 2018 , where the total production in 2018 was 8,541 tons.

Strawberries are horticultural commodities that are easily damaged after harvest. If the fresh handling during storage and sale is not appropriate, it causes the strawberries to be damaged, both physical damage and mechanical damage. Physical damage that occurs to strawberries during storage at different storage temperatures is the change in color of the strawberry skin to brown and the occurrence of shriveling of the strawberries. Mechanical damage that occurs is a decrease in the water content of strawberries during storage. According to Mitcham et al. (2000), strawberries have a fairly high respiration rate of 25-50 CO2 kg-1 hour-1 at a temperature of $10 \mathrm{oC}$. Therefore, strawberries have a limited shelf life and are easily damaged. 
The quality of fruit storage will last longer if the respiration rate is low and transpiration can be prevented by increasing the relative humidity, lowering the air temperature. In general, commodities that have a short shelf life have a high respiration rate or are sensitive to low temperatures (Tranggono and Sutardi, 1990).

Damage to the fruit will affect the level of quality of strawberries to the hands of consumers, while consumers want the strawberries obtained to have good quality and in a fresh state. These damages, in addition to causing a decrease in physical quality, also cause a decrease in nutritional value, it is necessary to immediately make efforts to maintain the quality of strawberries until they reach consumers.

The treatment that can maintain product quality is by storing it at cold temperatures. Cold temperatures can stop the activity of enzymes contained in the product so that the process of respiration and transpiration in the product can be reduced. In addition, cold temperatures can also prevent the product from being attacked by microorganisms outside the product which can accelerate the decline in product quality.

Cold storage is one of the most widely used ways to extend the shelf life of fruit to keep it fresh and to control fruit from spoilage. The use of various storage temperatures can extend the shelf life and maintain the quality of the fruit. Storage of strawberries after harvest is carried out at temperatures that are not constant causing physical damage to strawberries, therefore it is necessary to study the right temperature and humidity for strawberry storage.

\section{METHODS}

\section{A. Materials and Tools}

The materials used in this study were fresh strawberries that were ready for harvest with a uniform maturity level of $7 \mathrm{~kg}$.

The tools used are automatic refrigerator (cooling machine), digital force gauge measuring fruit hardness at a certain point on the fruit, refractometer to determine the total dissolved solids in strawberries, thermometer, digital scale, caliper, measuring cup, aluminum cup, thermohygometer, and ovens.

\section{B. Research Design}

Strawberries that have been harvested are immediately stored at room temperature and cooling temperatures of $10 \mathrm{oC}$ and $15 \mathrm{oC}$, observations are made every day. This research was conducted using the Factorial Design method in a Randomized Block Design (RAK) which consisted of 2 factors and 3 groups. The form of the analysis model is to examine the influence of two factors (called factorial A x B), with factor A having an a level and factor B having a b level (Yitnosumarto, 1993), namely:

Factor A = Storage space

$\mathrm{T} 1=$ Refrigerator temperature $(10 \mathrm{oC})$ and, 
$\mathrm{T} 2=$ Refrigerator temperature $(15 \mathrm{oC})$

Factor $\mathrm{B}=$ Amount of humidity

$\mathrm{K} 1=$ Humidity $65 \%$

$\mathrm{K} 2=$ Humidity $75 \%$ and,

$\mathrm{K} 3=$ Humidity $85 \%$

In this design, the groups or blocks are:

Group $1=$ Rack 1 (top shelf)

Group 2 = Rack 2 (middle shelf)

Group 3 = Rack 3 (bottom shelf)

C. Research Implementation

The strawberries used in this study were fresh strawberries harvested directly from the farmer's land, then the strawberries were brought to the laboratory using containers or cardboard to avoid mechanical damage. In the laboratory, strawberries are immediately cleaned of all impurities, after cleaning, the strawberries are weighed, diameter measurements are taken, the volume measurements for the fruit to be sampled are taken to collect weight loss observation data, diameter changes, and volume losses, as well as labeling each fruit. to be stored at different storage temperatures. For the treatment used 3 different temperatures, namely the treatment temperature of $10{ }^{\circ} \mathrm{C}, 15$ ${ }^{\circ} \mathrm{C}$ and room temperature treatment as a control.

Before the strawberries are put into the cooling room, the tool is operated and the temperature settings are $10 \mathrm{oC}, 15 \mathrm{oC}$ and humidity is $65 \%, 75 \%, 85 \%$. The relative humidity can be adjusted by using a relative humidity control program language application to run the relative humidity water pump driver which is performed on the BASCOM_AVR version 1.11.9.0 application. For room temperature treatment, strawberries were only placed in an open room, then observations were made on the temperature and humidity of the storage room.

Observation

Observations made on strawberries were three different temperature treatments, namely the treatment at $10 \mathrm{oC}$ and $15 \mathrm{oC}$ with a combination of humidity $65 \%, 75 \%, 85 \%$ and room temperature as a control. Observations were made every day until the strawberries were not accepted by consumers, which was marked by the criteria for the appearance of brownish color, softness, and the taste of the strawberries began to change. Data collection time is carried out every day at 13:00 WIB. Parameters observed were: color, density, weight loss, diameter loss, volume loss, shape, hardness, total dissolved solids, and water content.

\section{RESULT AND DISCUSSION}

Degradation of fruit color can be used as an indicator to determine the level of maturity in strawberries. The color of the fruit can be seen to determine the level of change in the maturity of the strawberry. The long storage time causes the strawberries to change color. Color changes in fruit can be observed every day using a digital 
camera, then color data processing is carried out using digital image software. The red, green and blue color index graphs for strawberries can be seen in Figures 1, 2, and 3.

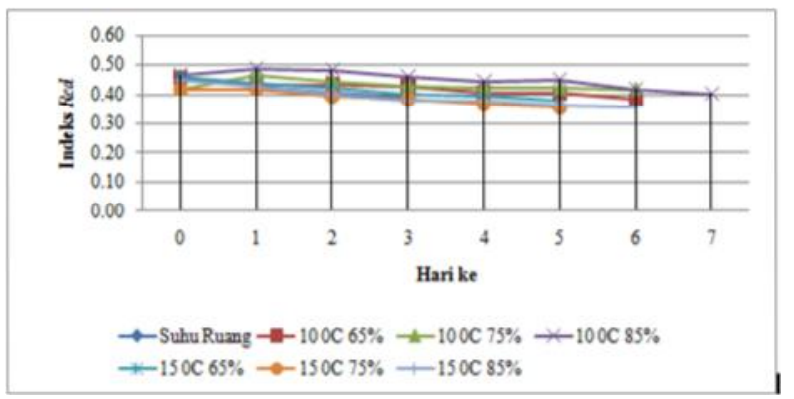

Fig. 1 Strawberry Red Index Graph during Storage

Based on Figure 1, the red color index value in strawberries has decreased. At room temperature the decrease in the red color index was faster than at $10 \mathrm{oC}$ and 15 $\mathrm{oC}$, this was due to the influence of environmental temperature and humidity during storage. The higher the temperature, the red color change process is faster than the lower temperature. At low temperatures, strawberries experienced a decrease in the red color index longer than at room temperature, this is because low temperatures will slow down the red color change in strawberries, as well as the effect of the moisture treatment used. According to Santoso (2006), after harvesting fruits and vegetables still continue their metabolic processes and physiological activities, therefore the composition and quality of commodities will experience changes. During the ripening process, fruits and vegetables undergo some noticeable changes in color, texture, and smell (Pantastico, 1997).

Observation of the green color index value on color degradation in strawberry storage can be seen in Figure 2.

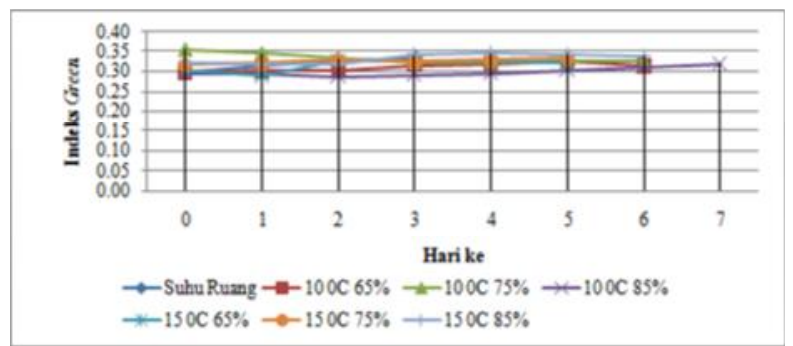

Fig 2. Strawberry Green Index Graph during Storage

Based on Figure 2, the observation data of the green color index in strawberries during storage at a temperature of $10 \mathrm{oC}, 15 \mathrm{oC}$ and room temperature changed. At a temperature of $10 \mathrm{oC}$, a temperature of $15 \mathrm{oC}$ with various humidity treatments, the green color index increased from the 0th day of storage to the last day of storage, this was caused by the effect of temperature and humidity on the fruit so that the green color index changes slowly. According to Pantastico (1997), the first 
sign of ripeness in fruit is the loss of green color, the color change occurs due to the enzymatic breakdown of chlorophyll so that other natural colors will open or appear.

Observation of the blue index value on color degradation in strawberry storage can be seen in Figure 3.

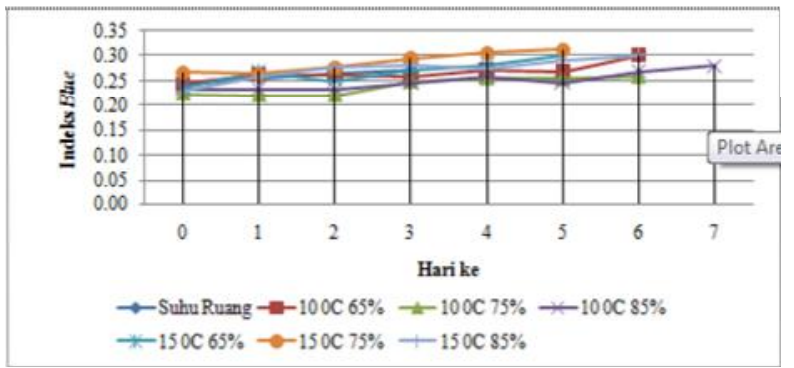

Fig 3. Strawberry Blue Index Graph during Storage Temperature

Based on Figure 3, the blue color index in strawberries during storage at $10 \mathrm{oC}, 15 \mathrm{oC}$ and room temperature increased. The increase in blue color at a temperature of $10 \mathrm{oC}$ and $15 \mathrm{oC}$ occurred in all humidity treatments slowly, this was caused by the effect of temperature and humidity on strawberries which were able to slow down changes in the blue index so that the increase in the blue index value on day 0 until strawberry storage on the last day did not too big. At room temperature the increase in the blue color index increases every day, this is because storage at high temperatures is not able to inhibit respiration, transpiration and includes color changes in strawberries. The color contained in horticultural products is influenced by the presence of pigments. According to Winarno (2008), the green color is usually caused by chlorophyll pigments, the blue color is usually caused by anthocyanins, the red color is caused by lycopene or anthocyanin pigments, and the yellow color is caused by xanthophyll pigments.

\section{Density}

Density is the ratio between mass and volume. To measure the density of strawberries, you can compare the value of the volume of strawberries with the value of the volume of the strawberry. Strawberry density graph can be seen in Figure 4.

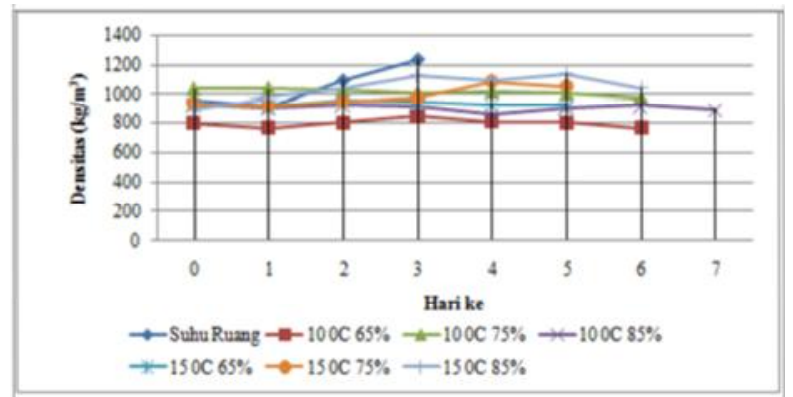

Fig 4. Graph of Strawberry Density Value during Storage 
Based on Figure 4 changes in the density of strawberries during storage at 10 $\mathrm{oC}, 15 \mathrm{oC}$ and room temperature, there was an increase and decrease in the density value of strawberries. On the storage of strawberries at room temperature, the density value on the 0th day of $953 \mathrm{~kg} / \mathrm{m} 3$ increased on the 2 nd day of $1096 \mathrm{~kg} / \mathrm{m} 3$ and the $3 \mathrm{rd}$ day of $1236 \mathrm{~kg} / \mathrm{m} 3$, this is because the storage of strawberries at room temperature has changed the volume value. and high weight values that affect the value of the density of strawberries. In addition, at a temperature of $15 \mathrm{oC}, 75 \%$ humidity and $15 \mathrm{oC}, 85 \%$ humidity, the density value also increases, this is because at high temperatures transpiration is greater than at low temperatures, which makes the volume and weight values in strawberries change because the fruit changes. becomes wrinkled and soft, so that the volume and weight values of the fruit also decrease due to transpiration which causes the water in the fruit to decrease. Fruit shrinkage during storage is due to the loss of water content in the fruit due to an irreplaceable transpiration process causing damage to the fruit to begin to occur (Santoso, 2006).

The following is a table and ANOVA analysis of the effect of group, temperature, humidity, and the interaction of temperature and humidity on the density of strawberry fruit. The anova table of strawberry fruit density during storage can be seen in Table 1.

\begin{tabular}{|l|l|l|l|l|l|l|}
\hline $\begin{array}{l}\text { Sumber } \\
\text { Keseragaman }\end{array}$ & $\begin{array}{l}\text { Jumlah } \\
\text { Kuadrat }\end{array}$ & $\begin{array}{l}\text { Derajat } \\
\text { Bebas }\end{array}$ & $\begin{array}{l}\text { Kuadrat } \\
\text { Tengah }\end{array}$ & F & Sig. & Ket \\
\hline Kelompok & 44819,293 & 2 & 22409,647 & 2,367 & 0,144 & NS \\
\hline Suhu & 28664,161 & 1 & 28664,161 & 3,028 & 0,112 & NS \\
Kelembaban & 63261,310 & 2 & 22409,647 & 3,341 & 0,077 & NS \\
Suhu<<Kelembaban & 27778,614 & 2 & 13889,307 & 1,467 & 0,276 & NS \\
Galat & 94661,287 & 10 & 9466,129 & & & \\
Total & $1,634 \times 10^{7}$ & 18 & & & & \\
\hline
\end{tabular}

Table 1. Anova Density of Strawberries during Storage

Tests on the groups that can be seen in Table 1, obtained a significant value of 0.114 , then $\mathrm{H} 0$ is accepted and $\mathrm{H} 1$ is rejected because the significant value is greater than 0.05 , which means that there is no effect of different groups on the observed weight loss of strawberries during storage. Testing on temperature obtained a significant value of 0.112 , then $\mathrm{H} 0$ was accepted and $\mathrm{H} 1$ was rejected because the significant value was greater than 0.05 , which means that there was no effect of different temperatures on the observed weight loss of strawberries during storage. Tests on humidity obtained a significant value of 0.077 then $\mathrm{H} 0$ is accepted and $\mathrm{H} 1$ is rejected because the significant value is greater than 0.05 , which means that there is no different effect of humidity on the observed weight loss of strawberries during storage. Testing the interaction between temperature and humidity obtained a significant value of 0.276 , then $\mathrm{H} 0$ was accepted and $\mathrm{H} 1$ was rejected because the significant value was greater than 0.05 , which means that there was no interaction between temperature and humidity in the observed weight loss of strawberries during storage.

3. Weight Loss

During the storage process, strawberries undergo physical changes, one of which is weight loss. Strawberry fruit weight loss can be measured with a digital scale. 
Fruit weight decreases during storage due to the process of respiration and transpiration. Strawberry fruit weight loss graph can be seen in Figure 5.

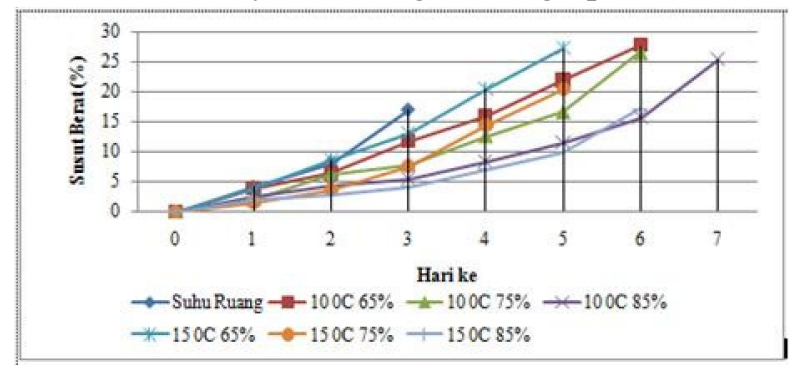

Based on Figure 5, it can be seen the increase in weight loss of strawberries for all types of temperature and humidity treatments starting from the first day of storage to the last day of storage. The highest value of weight loss occurred at storage temperature of $10 \mathrm{oC}$, humidity of $65 \%$, which was $27.724 \%$, this was due to faster transpiration of strawberries because strawberries were stored at a fairly low humidity of $65 \%$. The lowest value of weight loss occurred at room temperature storage, which was $17.005 \%$, this was because at room temperature the shelf life of strawberries only lasted up to 3 days, the fruit was damaged and observations were stopped.

At a temperature of $15 \mathrm{oC}$ with a humidity of $85 \%$, the weight loss value of strawberries is almost the same as the weight loss at room temperature which is $17.181 \%$, this is because at room temperature the humidity is quite high, namely $80 \%$ to $82 \%$. The increase in weight loss was due to during storage, there was a transpiration process which caused the water content of the fruit to decrease. The higher the storage temperature and the lower the humidity, the faster the transpiration process will occur.

The existence of the transpiration process not only causes the water content to decrease, but also causes a decrease in quality, such as wrinkles, softness, and rot. This is in accordance with what Muchtadi (1992) said, that the weight loss of stored vegetables and fruits is mainly due to water loss. Loss of water during storage not only reduces weight, but can also degrade quality and cause damage.

During storage, strawberries at room temperature only last for 3 days, while storage at $10 \mathrm{oC}$ with $85 \%$ humidity of strawberries lasts up to 7 days. At room temperature storage, anaerobic respiration occurs in strawberries, causing spoilage in strawberries. For a temperature of $10 \mathrm{oC}$ the level of damage during storage is lower, this is because at a temperature of $10 \mathrm{oC}$ the activity of fruit tissue is inhibited due to inappropriate environmental conditions (Adnan, 1986).

The following is a table and ANOVA analysis of the effect of groups, temperature, humidity, and the interaction of temperature and humidity on the weight loss of strawberries. The anova table of strawberry fruit weight loss during storage can be seen in Table 2. 


\begin{tabular}{l|l|l|l|l|l|l}
\hline $\begin{array}{l}\text { Sumber } \\
\text { Keseragaman }\end{array}$ & $\begin{array}{l}\text { Jumlah } \\
\text { Kuadrat }\end{array}$ & $\begin{array}{l}\text { Derajat } \\
\text { Bebas }\end{array}$ & $\begin{array}{l}\text { Kuadrat } \\
\text { Tengah }\end{array}$ & Finme & Sig. & Ket \\
\hline Kelompok & 49,201 & 2 & 24,601 & 1,600 & 0,250 & NS \\
Suhu & 16,207 & 1 & 16,207 & 1,054 & 0,329 & NS \\
Kelembaban & 68,955 & 2 & 34,447 & 2,243 & 0,157 & NS \\
Suhu><Kelembaban & 5,733 & 2 & 2,866 & 0,186 & 0,833 & NS \\
Galat & 153,742 & 10 & 15,374 & & & \\
Total & 1994,449 & 18 & & & & \\
\hline
\end{tabular}

Table 2. Anova Density of Strawberries during Storage

Tests on groups that can be seen in Table 2, obtained a significant value of 0.250 , then $\mathrm{H} 0$ is accepted and $\mathrm{H} 1$ is rejected because the significant value is greater than 0.05 , which means that there is no effect of different groups on the results of observations of strawberry fruit weight loss during storage. Testing on temperature obtained a significant value of 0.329 , then $\mathrm{H} 0$ is accepted and $\mathrm{H} 1$ is rejected because the significant value is greater than 0.05 , which means that there is no effect of different temperatures on the observed weight loss of strawberries during storage. The humidity test obtained a significant value of 0.157 , so $\mathrm{H} 0$ was accepted and $\mathrm{H} 1$ was rejected because the significant value was greater than 0.05 , which means that there was no different effect of humidity on the observed weight loss of strawberries during storage. Testing the interaction between temperature and humidity obtained a significant value of 0.833 , then $\mathrm{H} 0$ is accepted and $\mathrm{H} 1$ is rejected because the significant value is greater than 0.05, which means that there is no interaction effect between temperature and humidity on the observed weight loss of strawberries during storage.

4. Volume Loss

Measurement of volume in strawberries using a measuring cup. The fruit used to measure the volume during the observation was the same fruit from day 0 to the last day of observation. Strawberry volume loss graph can be seen in Figure 6 .

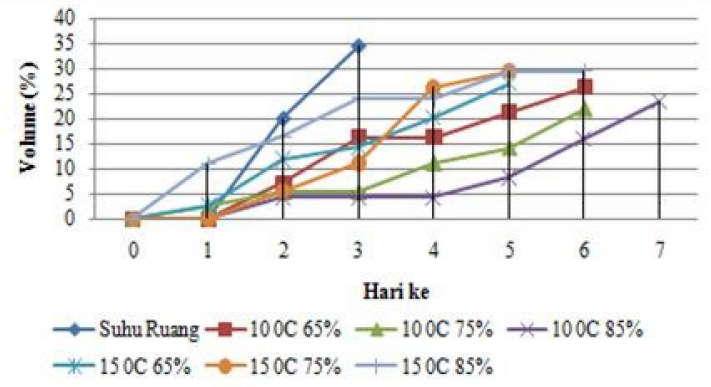

Fig 6. Graph of Strawberry Volume Loss during Storage

Based on Figure 6, it can be seen that there was an increase in the volume loss of strawberries during storage. The highest volume shrinkage value occurred at room temperature, which was $34.44 \%$, this was because at high temperatures the strawberries experienced rapid transpiration, causing the strawberries to become soft and wrinkled. The lowest volume loss value occurred at $10 \mathrm{oC}$ storage temperature with $75 \%$ humidity of $21.95 \%$, this is because at $10 \mathrm{oC}$ temperature with $75 \%$ humidity the 
evaporation process on the fruit becomes slow so it does not cause the fruit to become wrinkled quickly.

This volume loss is caused by evaporation of water or transpiration during storage which causes a reduction in the amount of water in the strawberry so that the fruit wrinkle and volume shrinks. This is in accordance with what was conveyed by Santoso (2006), that fruit shrinkage during storage is due to the loss of water content in the fruit due to an irreplaceable transpiration process causing damage to the fruit to begin. Lack of water in strawberries will reduce the freshness of strawberries, so that strawberries will look more wrinkled and soft.

\section{Shape}

The measurement of the shape of the strawberry can be done by looking for the value of roundness (sphericity). The length, thickness and width of the strawberries were measured using a caliper, where the dimensions of the strawberries were expressed by length (dmajor), thickness (dminor) and width (dmoderate). The graph for observing the shape of a strawberry can be seen in Figure 7 .

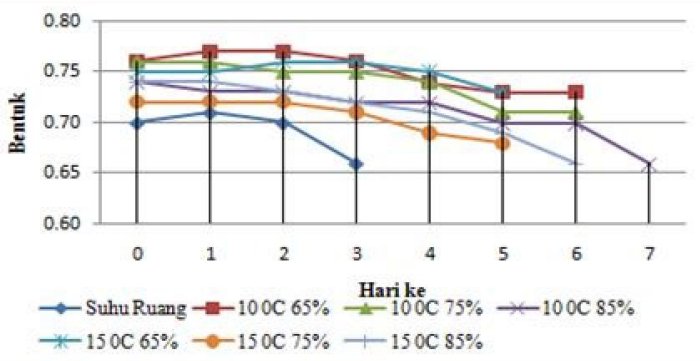

Fig 7. Graph of Strawberry Shape during Storage

Strawberries have various shapes, one of the shapes of strawberries is a round cone. The sphericity value can determine the shape of the strawberry itself. In Figure 7 it can be seen that the average value of strawberry roundness in each temperature and humidity treatment is 0.66 to 0.77 . Strawberry roundness value is not close to 1 , which means the shape of the strawberry is not round. From Figure 10, it can be seen that the value of strawberry shape for all storage treatments decreased from day 0 to the last day of storage. At room temperature, the value of strawberry shape 0.70 on the 0 th day decreased to 0.66 on the $3 \mathrm{rd}$ day, at $10 \mathrm{oC}$ humidity $65 \% 0.76$ on the 0 th day decreased to 0.73 day 6 , humidity $75 \% 0.76$ day- 0 decreased to 0.71 day 6 , and humidity $85 \%$ 0.74 day- 0 decreased to 0.66 day- 7 . In addition, at 15 oC humidity $65 \% 0.75$ day 0 decreased to 0.73 day 5 , humidity $75 \% 0.72$ day 0 decreased to 0.68 day 5 , and humidity $85 \% 0.74$ day- 0 decreased to 0.66 day- 6 , this was due to evaporation or loss of water from the fruit during storage which caused the skin of the fruit to shrivel and wither. The presence of shriveled cells as a result of high transpiration (Suhardjo, 1992). 
The following is a table and ANOVA analysis of the effect of group, temperature, humidity, temperature and humidity interaction on the shape of the strawberry fruit. Anova table of strawberry fruit shape during storage can be seen in Table 4.

\begin{tabular}{|l|l|l|l|l|l|l|}
\hline $\begin{array}{l}\text { Sumber } \\
\text { Keseragaman }\end{array}$ & $\begin{array}{l}\text { Jumlah } \\
\text { Kuadrat }\end{array}$ & $\begin{array}{l}\text { Derajat } \\
\text { Bebas }\end{array}$ & $\begin{array}{l}\text { Kuadrat } \\
\text { Tengah }\end{array}$ & F hinum & Sig. & Ket \\
\hline Kelompok & 0,000 & 2 & 0,000 & 0,105 & 0,901 & NS \\
Suhu & 0,001 & 1 & 0,001 & 0,269 & 0,615 & NS \\
Kelembaban & 0,004 & 2 & 0,002 & 1,074 & 0,378 & NS \\
Suhu><Kelembaban & 0,001 & 2 & 0,001 & 0,277 & 0,763 & NS \\
Galat & 0,021 & 10 & 0,002 & & & \\
Total & 9,619 & 18 & & & & \\
\hline
\end{tabular}

Tests on groups that can be seen in Table 4, obtained a significant value of 0.901 , then $\mathrm{H} 0$ is accepted and $\mathrm{H} 1$ is rejected because the significant value is greater than 0.05 , which means that there is no effect of different groups on the results of observations of strawberry fruit shape during storage. Testing on temperature obtained a significant value of 0.615 , then $\mathrm{H} 0$ is accepted and $\mathrm{H} 1$ is rejected because the significant value is greater than 0.05 , which means that there is no effect of different temperatures on the results of observations of strawberry fruit shape during storage. Duncan's further test could not be carried out on the temperature variable because the program could not operate 2 variables. The humidity test obtained a significant value of 0.378 , so H0 was accepted and $\mathrm{H} 1$ was rejected because the significant value was greater than 0.05 , which means that there was no different effect of humidity on the results of observing the shape of strawberries during storage. Testing the interaction between temperature and humidity obtained a significant value of 0.763 , then $\mathrm{H} 0$ is accepted and $\mathrm{H} 1$ is rejected because the significant value is greater than 0.05 , which means that there is no interaction between temperature and humidity in the observations of the shape of strawberries during storage.

\section{Shrink Diameter}

Measure the diameter of the strawberry using a caliper. The diameter taken on the fruit is the thick diameter. Diameter data were taken from the same sample each observation during storage (fixed sample). Graphs of differentiating diameters can be seen in Figure 8.

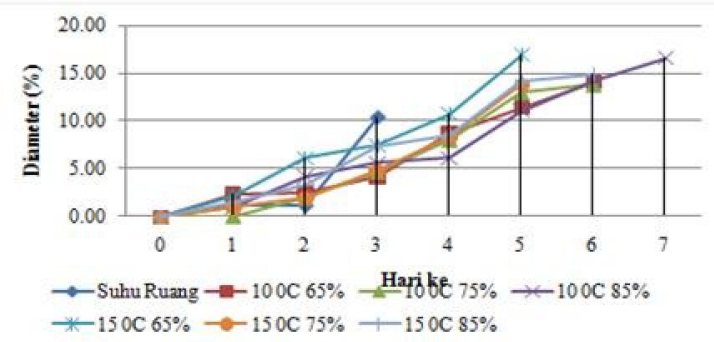

In Figure 8 it can be seen that there is a shrinkage in the diameter of the strawberries in each temperature and humidity treatment. The highest diameter shrinkage occurred at a storage temperature of $15 \mathrm{oC}$ with a humidity of $65 \%$, i.e. 
$16.95 \%$, this was due to the fact that at a higher temperature storage with less humid air, the strawberries evaporated faster, so that the strawberries changed shape more quickly than with strawberries stored at lower temperatures in very humid air.

The lowest diameter shrinkage occurred at room temperature, which was $10.40 \%$. This diameter shrinkage is due to the respiration process in the fruit during storage, this activity results in structural changes in the fruit, as a result the fruit becomes wrinkled, wrinkled, and softened, so that the diameter of the fruit decreases. The diameter shrinkage of the fruit occurs due to water loss during storage. According to Muchtadi (1992), a small loss of water in fruits and vegetables may not be a problem, but a heavy loss will cause wilting and wrinkling.

\section{Violence}

Strawberry fruit hardness was measured using a digital force gauge type FGS-5S with a puncture area diameter of $0.01 \mathrm{~m}$ and a cross-sectional area of $\backslash \mathrm{u} 200 \mathrm{~b} \backslash \mathrm{u} 200 \mathrm{bthe}$ puncture area $(\mathrm{m} 2) 0.0000785$. The results of the average measurement of the change in strawberry hardness can be seen in Figure 9.

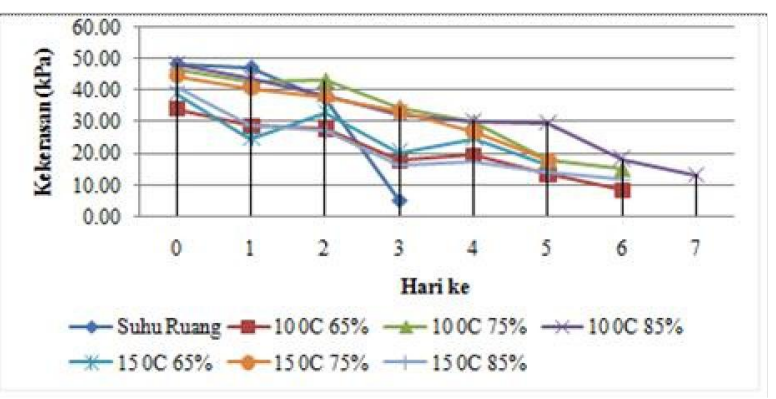

Based on Figure 9, it can be seen that the average initial hardness of strawberries ranges from $34.11 \mathrm{kPa}$ to $48.41 \mathrm{kPa}$. During storage of strawberries from the first day to the last day of storage, the fruit hardness decreased with each temperature and humidity treatment. Based on the hardness values obtained during the observation, it can be seen that the hardness values of strawberries ranged from 5.52 to $18.12 \mathrm{kPa}$ the fruit was no longer suitable for consumption. The hardness that decreased the fastest was storage at room temperature, where at room temperature the hardness value was $48.41 \mathrm{kPa}$ on the 0th day to $5.52 \mathrm{kPa}$ on the $3 \mathrm{rd}$ day, this was because at room temperature the transpiration process in the fruit was very high. This causes the fruit to wrinkle and soften faster. In cold storage, the hardness of strawberries did not decrease drastically, this was because at cold temperatures they were able to restrain the rate and transpiration of the fruit. According to Pantastico (1997), the composition of the fruit tissue also determines the firmness of the fruit. 
Duncan's further test needs to be done to see the effect of each humidity on the observation results if $\mathrm{H} 1$ is accepted. The Duncan Post Hoc Test further test table can be seen in Table 7 .

Table 7. Duncan Post Hoc Test Further Test The Effect of Moisture on Hardness of Strawberries during Storage

\begin{tabular}{lcccc}
\hline Humidity & $\mathrm{N}$ & \multicolumn{3}{c}{ Subset } \\
\cline { 3 - 5 } & & 1 & 2 & 3 \\
\hline Humidity $65 \%$ & 6 & 24,0867 & & \\
Humidity $85 \%$ & 6 & & 26,7850 & \\
Humidity $75 \%$ & 6 & & & 33,3783 \\
Sig. & & 1,000 & 1,000 & 1,000 \\
& & & &
\end{tabular}

Based on Table 7, it can be seen that the humidity of $85 \%$ is very different from the humidity of $75 \%$ and $65 \%$, the humidity of $75 \%$ is very different from the humidity of $65 \%$.

Testing the interaction between temperature and humidity obtained a significant value of 0.000 , then $\mathrm{H} 0$ was rejected and $\mathrm{H} 1$ was accepted because the significant value was less than 0.01 , meaning that the interaction between temperature and humidity was significantly different on the hardness of strawberries during storage.

Duncan's further test needs to be done to see the effect of each humidity on the observation results if $\mathrm{H} 1$ is accepted. The Duncan Post Hoc Test further test table can be seen in Table 9 .

Table 9. Duncan Post Hoc Test Further Test Effect of Humidity on Total Dissolved Solids during Storage.

\begin{tabular}{llll}
\hline Humidity & $\mathrm{N}$ & \multicolumn{2}{l}{ Subset } \\
\cline { 3 - 4 } & & 1 & 2 \\
\hline Humidity $85 \%$ & 6 & 7,1350 & \\
Humidity $75 \%$ & 6 & 7,5183 & 7,5183 \\
Humidity $65 \%$ & 6 & & 7,8667 \\
Sig. & & 0,136 & 0,172 \\
& & & \\
\hline
\end{tabular}

Based on Table 9 , it can be seen that the humidity of $85 \%$ is not significantly different from that of $75 \%$ humidity, but it is significantly different from that of $65 \%$ of humidity and $75 \%$ of humidity is not significantly different from that of $65 \%$ of humidity. Testing the interaction between temperature and humidity obtained a significant value of 0.000 , then $\mathrm{H} 0$ was rejected and $\mathrm{H} 1$ was accepted because the significant value was less than 0.01 , which means that the interaction between temperature and humidity was significantly different in the total soluble solids of strawberries during storage. 


\section{CONCLUSION}

Based on the results of the research that has been done, several conclusions can be drawn, namely:

1) Storage of strawberries at low temperatures with high humidity treatment can protect the storage of fruits from physical and chemical damage

2) The best storage of strawberries is storage at a temperature of $10 \mathrm{oC}$ with a humidity of $85 \%$ which can last up to 7 days, while at room temperature the shelf life of strawberries only lasts 3 days. So the storage of strawberries at a temperature of $10 \mathrm{oC}$ with a humidity of $85 \%$ can extend the shelf life of strawberries by 4 days.

From the results of the research that has been done, it is recommended to store strawberries at a low temperature of $10 \mathrm{oC}$ and humidity treatment of $85 \%$. Furthermore, it is suggested to further provide more treatments such as variations in temperature, humidity and varying the type of packaging on storage.V.

\section{REFERENCES}

[1] Adnan, M. 1986. Refrigeration and Freezing of Foodstuffs. Inter-University Center for Food and Nutrition. Yogyakarta: Gadjah Mada University.

[2] Central Bureau of Statistics. 2020. Development of Several Key Socio-Economic Indicators of Indonesia

[3] Mitcham, E.J., C.H. Crisosto and A.A. Kader, 2000. Recommendation for Maintaining Postharvest Quality. Department of Vegetable Crops, University of California, Davis.

[4] Muchtadi, T.R. 1992. Food Science. Department of Education and Culture. Directorate General of Higher Inter-University Center for Food and Nutrition. Bogor: Bogor Agricultural University.

[5] Pantastico, ER. B. 1997. Post Harvest Physiology Handling and Utilization of Tropical and Subtropical Fruits and Vegetables. Kamariyani., translator; Kingpin T., editor. Yogyakarta: Gadjah Mada University PressGadjah Mada University. Translation from: Postharvest Physiology, Handling and Utilization of Tropical and Sub-tropical Fruits and Vegetables. 4th ed..

[6] Santoso. 2006. Fresh Material Preservation Technology. Malang: Faperta Widyagama University Malang.

[7] Suhardjo, 1992, Principles of Nutrition. Yogyakarta: Kanisius.

[8] Tranggono and Sutardi. 1990. Biochemistry and Postharvest Technology. PAU Food and Nutrition. Yogyakarta: UGM.

[9] Wills R., McGlasson B., Graham D., and Joyce D. 2007. Postharvest, an Introduction to the Physiology and Handling of Fruits, Vegetables and Ornamentals. 4th ed. Sydney: University of New South Wales Press.

[10] Winarno, F.G. 2008. Food Chemistry and Nutrition. Bogor: M-Brio Press. 